American Journal of Pharmaceutical Education 2020; 84 (1) Article 7250.

\title{
BRIEF
}

\section{An Applied Improvisational Pharmacy Communication Workshop Implemented During Orientation for First-Year Pharmacy Students}

\author{
Erin E. Donovan, PhD, ${ }^{\text {a,b,c }}$ Laura E. Brown, PhD, ${ }^{\mathrm{c}}$ Sharon K. Rush, BS, ${ }^{\mathrm{b}}$ Mackenzie R. Greenwell, PhD, ${ }^{\mathrm{a}}$ \\ Billy Table, MA, ${ }^{a}$ Yaguang Zhu, PhD, ${ }^{a}$ Kyle D. Kearns, MA $^{\mathrm{a}}$ \\ ${ }^{\text {a }}$ The University of Texas at Austin, Moody College of Communication, Austin, Texas \\ ${ }^{b}$ The University of Texas at Austin, College of Pharmacy, Austin, Texas \\ ${ }^{c}$ The University of Texas at Austin, Center for Health Communication, Austin, Texas
}

Submitted July 2, 2018; accepted June 25, 2019; published January 2020.

Objective. To deliver a brief, applied workshop in improvisational communication skills during the new student orientation for first-year Doctor of Pharmacy students and to assess students' perceptions about the experience.

Methods. Communication instructors developed a two-hour communication "boot camp" based on established principles of clear, responsive, flexible communication. They taught core skills through interactive applied improvisational exercises and facilitated debriefings. A questionnaire was administered following the workshop that asked students to rate the quality of the session and comment on its strengths and weaknesses.

Results. Of the 124 students who participated in the workshop, 95 (77\%) completed evaluations at the end. Their feedback was generally favorable: $90 \%$ of participants indicated that the boot camp improved their communication skills and $92 \%$ agreed that the activities were realistic and relevant to real-life scenarios. The students reported that they valued the chance to connect with classmates, learn how to adapt to different audiences, and explore how communication skills would be useful in professional settings.

Conclusion. This interactive program delivered valuable content in a short period of time. Student feedback suggested that they valued the expertise of communication instructors and the playful, active method of learning. The creation of the workshop was labor-intensive because of the formative research that guided it.

Keywords: communication skills, health communication, rapport building, applied improv, new student orientation

\section{INTRODUCTION}

Skillful communication is a cornerstone of successful health care and has been increasingly emphasized as a core competency in leading undergraduate and graduate health professions programs. ${ }^{1,2}$ Coalescing currents in the healthcare and educational landscapes have highlighted how critical it is for practicing pharmacists to interact well with their patients, colleagues, and communities. For example, as healthcare organizations seek to maximize efficiency, and medication distribution is progressively automated, pharmacists are becoming more integrated

Corresponding Author: Erin E. Donovan, Moody College of Communication, College of Pharmacy, \& Center for Health Communication, The University of Texas at Austin, 2405A Whitis Ave., Austin, TX 78712. Tel: 512-471-5251. Email: erindonovan@utexas.edu.

Note: Author Yaguang Zhu is now affiliated with the University of Arkansas, Fulbright College of Arts and Sciences, Fayetteville, AR into care teams and more involved in direct patient care., The Pharmacy Workforce Center's 2014 National Pharmacist Workforce Survey indicated that $50 \%-60 \%$ of pharmacists perform medication counseling and immunizations for patients, which is a four-fold increase from just 10 years prior. ${ }^{5}$

In response to such significant changes in a complex healthcare landscape where pharmacists have an everexpanding role, forward-thinking Doctor of Pharmacy (PharmD) programs are examining how their curricula can best equip students to be leaders in their field. The Accreditation Council for Pharmacy Education (ACPE) and the Center for the Advancement of Pharmacy Education (CAPE) have specified that graduates are expected to demonstrate communication knowledge, skills, and attitudes that will prepare them for clear, effective, appropriate communication with patients and colleagues. ${ }^{6}$ This includes active listening and information seeking; 


\section{American Journal of Pharmaceutical Education 2020; 84 (1) Article 7250.}

establishing rapport and building trust; demonstrating empathy; and communicating clearly and persuasively. In summary, there is agreement that entry-level graduates from PharmD programs need to learn a diverse array of communication skills so that they can improve patient health outcomes and succeed professionally. ${ }^{7-9}$

The need for communication instruction in pharmacy programs is demonstrable and the mandate is clear. The logical set of questions to address next is not about whether or why to implement communication training for PharmD students, but rather when and how. There are numerous methods and considerations for delivering this content, with variation in terms of how early, incremental, and didactic instruction tends to be. Few pharmacy schools emphasize extensive (ie, $>20$ hours of) experiential training in communication skills, and those that do are considered "innovative" according to Svensberg and colleagues' analysis of communication education in pharmacy programs. ${ }^{10}$ The University of Texas at Austin College of Pharmacy, in collaboration with teacherscholars from the university's College of Communication, has embarked upon an extensive, comprehensive revision of the program's communication curriculum. Taking a longitudinal approach to communication training, the curriculum includes a semester-long, formal pharmacy professional communication course co-coordinated by pharmacy and communication instructors, as well as brief training workshops and communication skills modules integrated into other core courses.

More work is needed to systematically investigate best practices for teaching communication to pharmacy students. A national survey of pharmacy school faculty members indicated widespread concern that communication instruction is not sufficiently developed or evaluated and, in fact, is rather haphazard. ${ }^{11}$ In addition, limited research has addressed pharmacy students' own views regarding their communication skills training. ${ }^{10}$ The present manuscript describes an evaluation of a theoretically and empirically grounded communication workshop for first professional year (P1) PharmD students during their new student orientation.

\section{METHODS}

The pedagogical principles of the workshop we designed were threefold: it was evidence-based, geared toward early intervention, and meant to be interactive and fun. First, the lesson plan we created was grounded in theoretical principles of effective interpersonal, group, and public communication. ${ }^{12-14}$ Empirical data from PharmD classroom observations and interviews with faculty members and students contributed to the learning objectives so that it addressed the particular needs and aspirations for this
PharmD program. The principles, learning objectives, and lesson plan were likewise informed by scholarly literature on pharmacy education. ${ }^{15,16}$

A second core principle of this communication training was that it would be ideal to reach students as early as possible in their PharmD experience. ${ }^{16}$ Therefore, the workshop was conducted during the week-long orientation for new students. Based on evidence from other instructional interventions, students took part in five academic modules intended to bring them to a similar baseline level of communication skills. ${ }^{17}$ This was the first time that any communication instruction had ever been delivered during orientation at this college of pharmacy. It was the consensus of the instructional team that students would benefit from communication training that began immediately upon starting the degree program and then was reinforced at multiple timepoints across their first three years of coursework, which is consistent with findings from other analyses of communication skills training in health profession programs. ${ }^{11,18,19}$ Furthermore, previous research has recognized orientation week as a special time of socialization where collegial interactions among P1s can help build a sense of community. ${ }^{20,25}$

With the goal of fostering early, positive connections among new classmates, the third principle of our P1 communication workshop was that it was supposed to be interactive, fun, and geared toward nimble skills rather than a rote learning experience. Consequently, we designed our lesson plan using an applied improvisational theater approach. Applied improvisation connects the training strategies of improvisational theater to real-world professional settings. It is based on the premises that many of the communication skills and habits that characterize effective improv performers are comparable to skills and habits that engender success in other interactions, and that they are best taught with experiential learning strategies. ${ }^{2,21-23}$ The applied improvisation approach is meant to give participants a chance to be present, relaxed, and playful, all in the name of cultivating greater comfort with interpersonal situations that require flexibility and thinking on the spot. ${ }^{24}$ Applied improvisation has been used in academic medicine settings to train medical students and residents to be more empathetic and develop authentic connections. ${ }^{2,22}$ Some prior evidence from the University of Arizona College of Pharmacy lends support to the use of applied improvisation to teach communication skills in pharmacy school settings. ${ }^{26}$

All study procedures were approved by the university's Institutional Review Board. Participants were required to complete a week of new student orientation immediately prior to the beginning of fall semester courses. The academic leveling session described in this manuscript was a communication skills workshop (referred to 


\section{American Journal of Pharmaceutical Education 2020; 84 (1) Article 7250.}

as a "boot camp" by the orientation leaders) that lasted two hours. The workshop was created and facilitated by the manuscript authors: a tenured faculty member in communication, an instructional postdoctoral fellow with a $\mathrm{PhD}$ in communication, four doctoral students in communication, and a clinical associate professor of pharmacy who is a community pharmacist and a core leader of the pharmacy school's communication initiative and experiential education efforts. The doctoral students were trained by the first and second authors to deliver the content.

Following a large group introduction and icebreaker, students were divided into four groups of approximately 25 students for breakout sessions. The breakout sessions involved a fast-paced series of interactive applied improvisation exercises and structured debriefs during which session facilitators led group discussions about the communication skills that had been demonstrated and practiced in each exercise. Leaders prompted students to consider how the skills translated to pharmacy professional settings and explained in greater detail how the skills have theoretical and empirical support in health communication scholarship. The progression of exercises presented to students during the breakout sessions was purposeful and had pedagogical value. Initial exercises aimed to help students become acquainted and build rapport early in the session so they would feel comfortable participating, speaking openly during debriefs, and learning from others as exercises became increasingly challenging. The specific exercises and debrief goals are summarized in Appendix 1.

Collecting student feedback was a priority in accordance with calls for examining learners' assessments of their communication skills training. ${ }^{10,27}$ The paper questionnaire developed by pharmacy faculty orientation leaders included a single item relevant to the communication workshop: "I found this session helpful prior to beginning the academic year" $(1=$ strongly disagree, $5=$ strongly agree). A questionnaire we designed to capture data specifically on the communication skills session was composed of two parts. Four quantitative items gauged students' satisfaction with the communication workshop and level of interest in additional communication skills training $(1=$ strongly agree, $6=$ strongly disagree). Four open-ended questions were included to elicit further insights about the workshop and its relevance to students' academic and professional experiences, such as "What about today's boot camp was most useful to you?" Students were given a quick response (QR) code that they scanned with their smartphones, which linked to an electronic Qualtrics (Qualtrics, Plano, TX) questionnaire that they could complete on their devices. No incentive for students to participate was provided. The second author took an exploratory qualitative approach to identifying themes from open-ended data, which involved sorting comments into topic categories, and then quantifying the valence of the comments.

\section{RESULTS}

Potential participants were 124 incoming P1 students who were attending pharmacy school full time. A final sample of 95 students completed their evaluations following the workshop. Sixty-eight percent of the incoming class were women and 32\% were men. Students' selfreported their race/ethnicity at the time of admission: $36 \%$ were Asian/Asian-American; 36\%, Caucasian/white; 21\%, Hispanic/Latino; 5\%, multiple races/ethnicities; $2 \%$, African-American/black; and 2\%, unreported. The cohort's mean undergraduate grade point average at time of admission was $3.5(\mathrm{SD}=0.5)$. The majority $(75 \%)$ of students had earned a bachelor's degree; $23 \%$ had earned only a high school diploma; and $2 \%$ had earned a master's degree.

Regarding participants' overall evaluation of the workshop, results revealed that the P1s were generally satisfied with the experience. The mean score on the item, "I found this session helpful..." was 3.6 out of 5. Ninety percent of students indicated that the boot camp improved their communication skills; $92 \%$ agreed that the activities were realistic and relevant to real-life scenarios; and 93\% indicated a preference for learning more. Students' survey responses are presented in Table 1. The open-ended data were analyzed to learn what the participants found to be particularly valuable about the session. Overall, $96 \%$ of the 274 comments from students were favorable. The themes that emerged are summarized here; representative student statements are in Table 2.

Analysis of the open-ended responses suggested that students found three features of the communication boot camp most valuable: building relationships with peers; becoming more audience-centered; and debriefing with peers and facilitators. Regarding the first theme, students appreciated the opportunity to establish relationships within their cohort and become more comfortable with one another. Second, students said that they found it useful to practice communicating in audience-centered ways and to work on explaining complex information creatively. For some students, the idea of tailoring messages to the receiver was new and important; others already were aware of the importance of adapting to others, yet still appreciated the chance to practice. Third, students indicated that the debrief portions of the workshop were helpful in reflecting on experiences from the communication session itself, as well as from previous professional 
American Journal of Pharmaceutical Education 2020; 84 (1) Article 7250.

Table 1. Responses of First-Year Doctor of Pharmacy Students to a Questionnaire Evaluating an Applied Improvisational Communication Workshop Implemented During Orientation

\begin{tabular}{|c|c|c|c|c|c|c|c|}
\hline & $\begin{array}{c}\text { Strongly } \\
\text { Agree, No. } \\
(\%) \\
\end{array}$ & $\begin{array}{c}\text { Agree, } \\
\text { No. }(\%)\end{array}$ & $\begin{array}{c}\text { Somewhat } \\
\text { Agree, No. } \\
(\%) \\
\end{array}$ & $\begin{array}{c}\text { Somewhat } \\
\text { Disagree, No. } \\
(\%) \\
\end{array}$ & $\begin{array}{c}\text { Disagree, } \\
\text { No. (\%) }\end{array}$ & $\begin{array}{c}\text { Strongly } \\
\text { Disagree, No. } \\
(\%) \\
\end{array}$ & $\begin{array}{c}\text { Mean } \\
(\text { SD) }\end{array}$ \\
\hline $\begin{array}{l}\text { I want more training in } \\
\text { communicating } \\
\text { effectively with others. }\end{array}$ & $28(29)$ & $41(43)$ & $20(21)$ & $3(3)$ & $3(3)$ & $1(1)$ & $2.1(1.0)$ \\
\hline $\begin{array}{l}\text { Additional training would } \\
\text { help me effectively } \\
\text { communicate with } \\
\text { others. }\end{array}$ & $34(36)$ & $38(40)$ & 17 (18) & $4(4)$ & $2(2)$ & $0(0)$ & $2.0(1.0)$ \\
\hline $\begin{array}{l}\text { The application of the boot } \\
\text { camp activities to } \\
\text { realistic scenarios was } \\
\text { clearly demonstrated. }\end{array}$ & $29(31)$ & $41(43)$ & $17(18)$ & $4(4)$ & $2(2)$ & $2(2)$ & $2.1(1.1)$ \\
\hline $\begin{array}{l}\text { The boot camp improved } \\
\text { my communication } \\
\text { skills. }\end{array}$ & $20(21)$ & $36(38)$ & $29(31)$ & $5(5)$ & $2(2)$ & $3(3)$ & $2.4(1.1)$ \\
\hline
\end{tabular}

$1=$ strongly agree, $6=$ strongly disagree

settings. They expressed that the opportunity to discuss the activities in their groups allowed them to share, extend, and apply what they learned. They heard what their new classmates had done to accomplish communicative goals.

Although most of the student feedback was positive, highlighting the relevance, applicability, and value of the communication skills boot camp, we were interested in and specifically sought suggestions for improvement.
One recommendation that students made was to ensure that the level of expertise of all breakout session facilitators was consistently high; some debriefs seemed to be infused with greater credibility because they were facilitated by more experienced instructors. Additionally, some students referred to the communication skills boot camp as an "icebreaker" that was more fun than informative, and others mentioned that the material felt redundant or rudimentary.

Table 2. Representative Comments From First-Year Doctor of Pharmacy Students Regarding What They Found Most Valuable From an Applied Improvisational Communication Workshop Implemented During Orientation

\begin{tabular}{l}
\hline Theme \\
Building Relationships \\
"It was nice to get out of my comfort zone and interact with my \\
fellow classmates in a fun but useful manner" \\
"Learning to communicate with my peers in a fun and stress \\
free way" \\
"I'm more comfortable with my classmates and can help them \\
or ask for help, or befriend them" \\
"I would be able to better relate with the patients and explain \\
things in a way that they can understand" \\
"Learning about effective ways to communicate with \\
individuals that do not have the same technical insight as I \\
do and establishing trust/common ground" \\
"Hearing other people's responses to the prompts/activities \\
was useful because it helped me think about explaining \\
things in different ways than I normally would" \\
"The various small games ultimately presented a bigger idea \\
and illustrated to us a key point in communication" \\
"Being able to debrief and dissect the skills behind effective \\
communication [was valuable]"
\end{tabular}




\section{American Journal of Pharmaceutical Education 2020; 84 (1) Article 7250.}

\section{DISCUSSION}

The primary purpose of this project was to design and evaluate a brief communication skills workshop for P1 PharmD students that could be delivered during their new student orientation. The overall assessment of the workshop was favorable, both from the learner and instructor perspectives. In sum, it was indeed possible to create a session that was evidence-based, entertaining, and interactive; promoted communication skill development and cohort cohesion; and capitalized on the opportunity to reach students immediately as they began their pharmacy school experience.

The design of the workshop was conceptually strong, as it was based on communication theory and research and carefully developed by a multidisciplinary team of communication and pharmacy experts. Evaluative data from learners confirmed that the session was well received. The P1 students who participated in the communication workshop expressed that they valued the chance to establish relationships within their cohort, learn about audience-centered communication, practice explaining complex information in creative ways, and extend and apply what they learned through discussion. Students seemed to enjoy the applied improvisation approach, as it was engaging, immersive, and experiential. The P1 students noted that it was useful to have structured debrief time so that they could understand more explicitly and abstractly how each applied improvisation exercise demonstrated tenets of good communication. The interactions and discussions helped to give the students a sense of the various communication situations they might encounter someday as practicing pharmacists, and they bolstered a sense of community, which was consistent with the outcomes of previous orientation programs. ${ }^{20}$

A limitation of this project is that it relied on selfreport questionnaire data. Also, not all students who participated in the workshop provided comments. Thus, our evaluation is subject to both selection bias and selfreport bias. The data did generate ideas for modifying future communication workshop sessions, however. To account for differences in skill, experience, and dynamism of breakout session facilitators, sessions may need to be conducted separately rather than concurrently, with the same set of facilitators running each of them and with the most experienced communication instructors taking the lead. More intensive training may be required so that the leaders feel comfortable with the applied improvisation techniques as well as the communication science behind them. Such training may help to amplify the sense of purpose behind the "play." By its very nature, a "leveling" session will be marked by some variation. A handful of comments indicated that the communication workshop seemed too much like icebreaker games, which gave us pause; we did not intend for the session to seem as though it lacked rigor. To enhance rigor in future sessions, we plan to avoid using the word "icebreaker," and to incorporate more targeted feedback to arouse "conscious incompetence," 28 in other words, make students more aware of communication skills they have yet to master and how it requires practice to do so.

It is important to reflect on the resources required to replicate this project, which has received extensive support from deans, department chairs, and directors in multiple units at our university. This orientation session was an instructional deliverable that was budgeted as part of the larger communication curriculum intervention. The intervention involves a core team of faculty members, an instructional postdoctoral scholar, and graduate teaching and research assistants whose time is supported via salary and course releases. The communication workshop we created received intellectual input from several faculty members and students who volunteered their time because of their dedication to the student experience and their interest in this as an educational and research opportunity. Our campus is home to a Center for Health Communication that provides infrastructure for these types of initiatives. Pharmacy programs have to be careful custodians of their students' and faculty members' time. The willingness of our college of pharmacy to include a communication workshop as an academic session during the new student orientation is a solid reminder that communication skills are valued, and hopefully has the potential to engender a culture of communication excellence across the college.

\section{CONCLUSION}

Although more work needs to be done, the applied improvisation-focused communication workshop was a worthwhile inclusion in PharmD students' first-year orientation. This session appeared to help students connect with their classmates, consider how to adapt to others while communicating, and see how their communication skills would be useful in professional settings. Ideally it will have set the stage for ongoing interest in learning communication skills and improving pharmacy practice.

\section{ACKNOWLEDGMENTS}

The authors thank the UT College of Pharmacy, Moody College of Communication, and the Center for Health Communication, in particular Dean M. Lynn Crismon, Dean Jay Bernhardt, Diane Ginsburg, Bryson Duhon, Renee' Acosta, and Mike Mackert. 


\section{American Journal of Pharmaceutical Education 2020; 84 (1) Article 7250.}

Conflicts: The authors were the communication workshop designers and facilitators.

\section{REFERENCES}

1. Donovan EE, Love B, Mackert M, Vangelisti A, Ring D. Health communication: a future direction for instructional communication research. Commun Educ. 2017;66(4):490-492.

2. Kaplan-Liss E, Lantz-Gefroh V, Bass E, et al. Teaching medical students to communicate with empathy and clarity using improvisation. Acad Med. 2018;93(3):440-443.

3. Pedersen CA, Schneider PJ, Scheckelhoff DJ. ASHP national survey of pharmacy practice in hospital settings: dispensing and administration. Am J Health-Syst Ph. 2014;72(13):1119-1137. 4. Pedersen CA, Schneider PJ, Scheckelhoff DJ. ASHP national survey of pharmacy practice in hospital settings: prescribing and transcribing-2016. Am J Health-Syst Ph. 2017;74(17):1336-1352.

5. Eckel FM. The pharmacist's expanded role. Pharm Times. 2015(Oct). 6. Medina MS, Plaza CM, Stowe CD, et al. Center for the advancement of pharmacy education 2013 educational outcomes. $\mathrm{Am}$ J Pharm Educ. 2013;77(8):Article 162.

7. Denvir P, Brewer J. "How dare you question what I use to treat this patient?": student pharmacists' reflections on the challenges of communicating recommendations to physicians in interdisciplinary health care settings. Health Commun. 2015;30(5):504-512.

8. Lambert BL. Face and politeness in pharmacist-physician interaction. Soc Sci Med. 1996;43(8):1189-1198.

9. Leape LL, Cullen DJ, Clapp MD, et al. Pharmacist participation on physician rounds and adverse drug events in the intensive care unit. JAMA. 1999;282(3):267-270.

10. Svensberg K, Kälvemark Sporring S, Lupattelli A, Olsson E, Wallman A, Björnsdottir I. Nordic pharmacy students' opinions of their patient communication skills training. Am J Pharm Educ. 2018;82(2):152-162. 11. Beardsley RS. Communication skills development in colleges of pharmacy. Am J Pharm Educ. 2001;65(4):307-314.

12. Knapp ML, Daly JA, ed. The SAGE Handbook of Interpersonal Communication. Thousand Oaks, CA: Sage; 2011.

13. Rubin RB, Martin MM. Development of a measure of interpersonal communication competence. Commun Res Rep. 1994;11(1):33-44. 14. Watzlawick P, Bavelas JB, Jackson DD. Pragmatics of Human Communication: A study of Interactional Patterns, Pathologies and Paradoxes. New York: W. W. Norton \& Company; 1967.
15. Liu M, Butler LM. Patient Communication for Pharmacy: A Case-Study Approach on Theory and Practice. Burlington, MA: Jones \& Bartlett Learning; 2017.

16. Wilson SE, Prescott J, Becket G. Empathy levels in first- and third-year students in health and non-health disciplines. Am J Pharm Educ. 2012;76(2):1-4.

17. McLaughlin JE, Khanova J, Persky A, Hathaway N, Cox W. Design, implementation, and outcomes of a three-week pharmacy bridging course. Am J Pharm Educ. 2017;81(7):6313.

18. Deveugele M, Derese A, De Maesschalck S, Willems S, Van Driel M, De Maeseneer J. Teaching communication skills to medical students, a challenge in the curriculum? Patient Educ Couns. 2005;58(3):265-270.E.

19. Rider EA, Hinrichs MM, Lown BA. A model for communication skills assessment across the undergraduate curriculum. Med Teach. 2006;28(5):e127-e134.

20. Poirier TI, Santanello CR, Gupchup GV. A student orientation program to build a community of learners. Am J Pharm Educ. 2007;71(1):A13.

21. Hoffmann-Longtin K, Rossing JP, Weinstein E. Twelve tips for using applied improvisation in medical education. Med Teach. 2018;40(4):351-356.

22. Watson K. Serious play: Teaching medical skills with improvisational theater techniques. Acad Med.

2011;86(10):1260-1265.

23. Hoffman A, Utley B, Ciccarone D. Improving medical student communication skills through improvisational theatre. Med Educ. 2008;42(5):537-538.

24. Egener B, Cole-Kelley K. Satisfying the patient, but failing the test. Acad Med. 2004;79(6):508-510.

25. Luiz Adrian JA, Zeszotarski P, Ma C. Developing pharmacy student communication skills through role-playing and active learning. Am J Pharm Educ. 2015;79(3):A44.

26. Boesen KP, Herrier RN, Apgar DA, Jackowski RM. Improvisational exercises to improve pharmacy students' professional communication skills. Am J Pharm Educ. 2009;73(2),A35.

27. Brown C, Hurst J, Davies H. Teaching communication skills specific to pediatrics in 40 minutes. Med Educ. 2008;42(5):538-539. 28. Howell WS. The Empathic Communicator. Bellmont, CA: Wadsworth; 1982. 
American Journal of Pharmaceutical Education 2020; 84 (1) Article 7250.

Appendix 1. Overview of Applied Situational Improvisation Pharmacy Communication Exercises Used in a Workshop for Entering First-Year Doctor of Pharmacy Students

\begin{tabular}{|c|c|c|c|}
\hline $\begin{array}{l}\text { Applied Improv } \\
\text { Exercise }\end{array}$ & Instructions & Learning Objectives & Debrief Points \\
\hline $\begin{array}{l}\text { Icebreaker (Large } \\
\text { Group) }\end{array}$ & $\begin{array}{l}\text { Introduce yourself to at least } \\
\text { three people, and find at least } \\
\text { two areas of common interest } \\
\text { with each of them. }\end{array}$ & $\begin{array}{l}\text { Practice effective question } \\
\text { asking, information seeking, } \\
\text { rapport building, active } \\
\text { listening, teamwork, and } \\
\text { responsiveness. }\end{array}$ & $\begin{array}{l}\text { Meeting new people is a part of } \\
\text { professional life. Finding ways } \\
\text { to connect with colleagues and } \\
\text { patients paves the way for } \\
\text { better social interactions. }\end{array}$ \\
\hline $\begin{array}{l}\text { Enemy/Protector } \\
\text { (Breakout Group) }\end{array}$ & $\begin{array}{l}\text { Individually and secretly choose } \\
\text { from your group one classmate } \\
\text { to be your "enemy," and one to } \\
\text { be your "protector." Then } \\
\text { circulate throughout the room } \\
\text { and attempt to keep your } \\
\text { protector positioned between } \\
\text { you and your enemy at all } \\
\text { times, without talking. }\end{array}$ & $\begin{array}{l}\text { Increase spatial awareness, } \\
\text { bodily awareness, reaction } \\
\text { times, and recognition that two } \\
\text { interactants may have different } \\
\text { understandings of each other's } \\
\text { roles. }\end{array}$ & $\begin{array}{l}\text { Warming up before an interaction } \\
\text { (eg, before beginning a work } \\
\text { shift) helps people focus their } \\
\text { energy so they can respond to } \\
\text { other people and situations } \\
\text { spontaneously and effectively. } \\
\text { This is important in fast-paced } \\
\text { environments like busy } \\
\text { community pharmacies where } \\
\text { people present a varied set of } \\
\text { needs and goals. }\end{array}$ \\
\hline $\begin{array}{l}\text { Time Traveler (Breakout } \\
\text { Group) }\end{array}$ & $\begin{array}{l}\text { In pairs: One partner plays the } \\
\text { role of a time traveler from the } \\
\text { past (eg, } 500 \text { years ago) who } \\
\text { does not recognize a } \\
\text { smartphone, know what it is } \\
\text { for, or understand that it is not } \\
\text { an object of evil. The other } \\
\text { partner must explain the } \\
\text { smartphone and convince the } \\
\text { time traveler that the phone is } \\
\text { not magical or dangerous. }\end{array}$ & $\begin{array}{l}\text { Be audience-centered/patient- } \\
\text { centered by tailoring } \\
\text { communication to the } \\
\text { knowledge, goals, and values } \\
\text { of the other person. Use } \\
\text { metaphors and analogies, } \\
\text { paired with simple } \\
\text { explanations, to communicate } \\
\text { complex ideas and alleviate } \\
\text { suspicions or fears. }\end{array}$ & $\begin{array}{l}\text { Good communication is } \\
\text { audience-centered. Analogies } \\
\text { help interaction partners bridge } \\
\text { knowledge gaps. Pharmacists } \\
\text { can use analogies to explain } \\
\text { why a particular medication or } \\
\text { inhaler works the way that it } \\
\text { does, or to describe the } \\
\text { physiology of diabetes to a low } \\
\text { health literate patient. }\end{array}$ \\
\hline $\begin{array}{l}\text { Zip - Zap - Zop } \\
\quad \text { (Breakout Group) }\end{array}$ & $\begin{array}{l}\text { Stand in a circle. With "diving } \\
\text { hands," gesture to another } \\
\text { student and say the words } \\
\text { "zip," "zap," or "zop," } \\
\text { alternating from student to } \\
\text { student as they repeatedly pass } \\
\text { off that sequence. }\end{array}$ & $\begin{array}{l}\text { Practice appropriate and effective } \\
\text { eye contact and gestures while } \\
\text { communicating verbally. } \\
\text { Anticipate that you can } \\
\text { become involved in the } \\
\text { interaction at any time, while } \\
\text { also remaining relaxed and } \\
\text { flexible enough to respond } \\
\text { with the appropriate word in } \\
\text { the sequence. }\end{array}$ & $\begin{array}{l}\text { Clear nonverbal communication } \\
\text { reinforces clear verbal } \\
\text { communication, which is } \\
\text { particularly useful when } \\
\text { handing off a task, project, } \\
\text { patient, or shift to another } \\
\text { healthcare professional. }\end{array}$ \\
\hline $\begin{array}{l}\text { Beaker/Bagel (Breakout } \\
\text { Group) }\end{array}$ & $\begin{array}{l}\text { Combine an everyday object and } \\
\text { a workplace item into a new, } \\
\text { imaginary product. Give a } \\
\text { brief, persuasive sales pitch } \\
\text { that describes the product's use } \\
\text { and value. }\end{array}$ & $\begin{array}{l}\text { Using audience-centeredness, } \\
\text { quickly and creatively describe } \\
\text { a new object and persuasively } \\
\text { communicate why it matters to } \\
\text { audience members. }\end{array}$ & $\begin{array}{l}\text { Pharmacists often need to clearly } \\
\text { communicate complex } \\
\text { information under time } \\
\text { constraints and maximize the } \\
\text { effectiveness of brief } \\
\text { encounters with patients and } \\
\text { other professionals. }\end{array}$ \\
\hline
\end{tabular}

